\title{
PENGARUH PENGGUNAAN SEPATU HAK TINGGI TERHADAP RISIKO TIMBULNYA VARISES PADA TUNGKAI BAWAH
}

\author{
${ }^{1}$ Bretha Arih Kitami S. Maha \\ ${ }^{2}$ S.H.R Ticoalu \\ ${ }^{2}$ Djon Wongkar
}

\author{
${ }^{1}$ Kandidat Skripsi Fakultas Kedokteran Universitas Sam Ratulangi Manado \\ ${ }^{2}$ Bagian Anatomi Histologi Fakultas Kedokteran Universitas Sam Ratulangi Manado \\ Email: brethaarihkitami@gmail.com
}

\begin{abstract}
Use of high heels above five centimeters can cause problems in the blood vessels. That is, akhiles tendon which is behind the heel and calf muscles are constantly in a state of tension. Depressed blood vessels, occurs dam and eventually lead to varicose veins. Varicose veins are veins are dilated tortuous so prominent on the surface of the skin. Objective: To determine the effect of use high heels on the risk of varicose veins in the lower limbs. Method: The type of this research used an observational research and using a cross sectional design. Result: The statistics determined that there was significant effect of use high heels on the risk of varicose veins in the lower limbs and $P$ value was 0.0001 . Conclusion: The statistics determined that there was significant effect of use high heels on the risk of varicose veins in the lower limbs.
\end{abstract}

Keywords: High heels, varicose veins

\begin{abstract}
Abstrak: Pemakaian sepatu hak tinggi di atas lima sentimeter dapat menyebabkan masalah pada pembuluh darah. Artinya, tendon Akhiles yang berada di tumit belakang dan otot betis terus-menerus dalam keadaan tegang. Pembuluh darah tertekan, terjadi bendungan dan akhirnya mengakibatkan varises. Varises adalah pembuluh darah balik yang melebar yang berliku-liku sehingga menonjol pada permukaan kulit. Tujuan: Untuk mengetahui pengaruh penggunaan sepatu hak tinggi terhadap resiko timbulnya varises pada tungkai bawah. Metode: Jenis penelitian yang digunakan yaitu penelitian observasional dengan menggunakan desain penelitian cross sectional. Hasil: Secara statistik ditetapkan bahwa terdapat pengaruh penggunaan sepatu hak tinggi terhadap risiko timbulnya varises pada tungkai bawah dengan $P=$ 0,0001. Simpulan: Secara statistik terdapat pengaruh penggunaan sepatu hak tinggi terhadap risiko timbulnya varises pada tungkai bawah.
\end{abstract}

Kata kunci: Sepatu hak tinggi, varises.

Sepatu merupakan salah satu yang ikut berperan dalam aktivitas seorang wanita dan memiliki fungsi kesehatan serta estetika. Sepatu yang baik harus memenuhi kedua fungsi itu. Dari segi kesehatan, sepatu melindungi dan menjaga kebersihan kaki serta membantu kaki menopang tubuh. Dari segi estetika, sepatu bisa membantu penampilan. ${ }^{1,2}$ Badan Survei di Amerika Serikat mencatat 59\% wanita menggunakan sepatu hak tinggi kurang lebih satu sampai delapan jam perharinya. ${ }^{2,3}$ Pemakaian sepatu hak tinggi dapat menyebabkan masalah pada pembuluh darah. Pemakaian sepatu hak tinggi di atas lima sentimeter membuat kaki terus-menerus menjinjit. Artinya, tendon Akhiles yang berada di tumit belakang dan otot betis terus-menerus dalam keadaan tegang. Pembuluh darah tertekan, terjadi bendungan dan akhirnya mengakibatkan 
varises. ${ }^{1}$ Varises atau varicose veins adalah pembuluh darah balik yang melebar yang berliku-liku sehingga menonjol pada permukaan kulit. Pada orang-orang tertentu pembuluh balik yang terdapat ditungkai dengan mudahnya mekar atau bengkak. Varises biasanya dapat terjadi di manamana, tetapi biasanya yang paling sering nampak adalah di bagian kaki karena letaknya yang rendah. Varises menyerang orang yang biasa berdiri terlalu lama dan apalagi dengan menggunakan sepatu hak tinggi. ${ }^{4,5}$ Varises berhubungan dengan kelemahan struktural tonus otot pembuluh vena. Gejala yang paling sering timbul adalah cepat lelah, keram pada kaki dan terasa nyeri terutama saat saat berdiri lama ataupun saat aktivitas yang banyak menggunakan kaki. Hal ini disebut sebagai claudication. Claudication berasal dari bahasa Latin "claudicare" berarti lemah. Claudication adalah rasa sakit atau cramping di bawah tungkai karena kurangnya darah mengalir ke otot. Rasa sakit yang biasanya menyebabkan orang merasa nyeri pada kaki. Penderita varises biasanya merasakan nyeri dan keram pada kaki, terutama pada saat berdiri maupun saat beraktivitas dan nyeri berkurang jika istirahat. Nyeri ini biasa disebut sebagai claudication intermitten. ${ }^{6}$ Pemakaian sepatu hak tinggi yang sering dapat membuat tonus otot melemah sehingga pembuluh darah balik meregang menyebabkan vena kehilangan kelenturannya sehingga vena meregang dan menjadi lebih panjang dan lebih lebar. ${ }^{4,5}$ Karena itu, penulis terdorong untuk melakukan penelitian mencari pengaruh penggunaan sepatu hak tinggi terhadap risiko timbulnya varises pada tungkai bawah dengan menggunakan claudication time pada SPG (Sales Promotion Girls) Matahari Departement Store Manado.

\section{METODE PENELITIAN}

Jenis penelitian yang digunakan dalam penelitian ini yaitu penelitian observasional dengan menggunakan desain penelitian cross sectional. Penelitian ini dilakukan di
Matahari Departement Store Manado selama bulan November 2012 sampai bulan Januari 2013 dengan menggunakan teknik purposive sampling. Populasi berjumlah 300 orang SPG Matahari Departement Store. Sampel didapatkan dari 30 orang SPG pengguna sepatu hak tinggi yang memenuhi kriteria serta 30 orang SPG bukan pengguna sepatu hak tinggi. Kriteria inklusi yaitu usia 20-30 tahun, berat badan ideal, belum pernah hamil atau melahirkan, masa kerja dua tahun atau lebih, rutinitas kerja berdiri dengan menggunakan sepatu hak tinggi 5-7 $\mathrm{cm}$, bekerja menggunakan sepatu hak tinggi lebih dari tiga jam perhari dan bersedia menjadi subjek penelitian. Kriteria eksklusi yaitu varises $(+)$ atau pernah mengalami varises, cidera pada kaki $(+)$, penggunaan sepatu hak tinggi kurang dari dua tahun dan melakukan olahraga yang menggunakan kaki minimal tiga kali seminggu. Alat yang digunakan dalam penentuan IMT yaitu dengan menggunakan timbangan berat badan dan pita pengukur tinggi (microtoise). Metode pemeriksaan Vascular system menggunakan treadmill untuk menghitung kapan terjadinya nyeri pada betis. Pada penelitian ini analisis data yang digunakan yaitu Independent sample T test.

\section{HASIL PENELITIAN}

\section{Karekteristik subjek penelitian}

Penelitian dilakukan pada 30 orang SPG yang memenuhi kriteria inklusi dan 30 orang SPG yang menggunakan sepatu hak kurang dari lima sentimeter.

\section{Deskripsi karakteristik menurut umur}

Subjek penelitian yang menggunakan sepatu hak tinggi berumur antara $20-28$ tahun dengan umur rata-rata 22,4 tahun. Subjek penelitian yang menggunakan sepatu hak tidak tinggi berumur antara 20-25 tahun dan umur rata-rata 21,1 tahun. Umur untuk keseluruhan berkisar antara 20-28 tahun dengan umur rata-rata 21,7 tahun. 


\section{Tinggi badan subjek penelitian}

Subjek penelitian yang menggunakan sepatu hak tinggi mempunyai tinggi badan antara 150-164 cm dengan tinggi badan ratarata $157 \mathrm{~cm}$. Subjek penelitian yang menggunakan sepatu hak tidak tinggi mempunyai tinggi badan antara 155-169 $\mathrm{cm}$ dan tinggi badan rata-rata $159,6 \mathrm{~cm}$. Tinggi badan untuk keseluruhan berkisar antara 150-169 cm dengan tinggi badan rata-rata 158,3 cm

\section{Berat badan subjek penelitian}

Subjek penelitian yang menggunakan sepatu hak tinggi mempunyai berat badan antara 41-55 kg dengan berat badan rata-rata $48 \mathrm{~kg}$. Subjek penelitian yang menggunakan sepatu hak tidak tinggi mempunyai berat badan antara $45-59 \mathrm{~kg}$ dan berat badan ratarata 50,8 kg. Berat badan untuk keseluruhan berkisar antara 41-59 kg dengan berat badan rata-rata $49,4 \mathrm{~kg}$.

\section{Tinggi hak sepatu subjek penelitian}

Subjek penelitian yang menggunakan hak sepatu tujuh sentimeter sebanyak 11 orang dengan presentase $18.33 \%$, subjek penelitian yang menggunakan hak lima sentimeter sebanyak 19 orang dengan presentase $31.67 \%$ sedangkan subjek penelitian yang menggunakan hak sepatu kurang dari lima sentimeter sebanyak 30 orang dengan presentase $50 \%$.

\section{Waktu Treadmill Subjek Penelitian}

Berdasarkan Tabel 1, dapat dideskripsikan bahwa subjek penelitian yang menggunakan hak sepatu 5-7 cm termasuk dalam kategori menggunakan sepatu hak tinggi terdiri dari 30 orang memiliki rata- rata waktu 170,57 detik, simpangan baku 48,954, nilai maksimum 255 detik sedangkan nilai minimum 110 detik. Untuk subjek penelitian yang menggunakan hak sepatu kurang dari lima sentimeter termasuk tidak menggunakan sepatu hak tinggi terdiri dari 30 orang memiliki rata-rata 284,07 detik, simpangan baku 66,460, nilai maksimum 401 detik dan nilai minimum 200 detik. Berdasarkan perolehan dapat disimpulkan bahwa rata-rata waktu untuk SPG yang memakai hak sepatu tinggi lebih kecil atau lebih cepat dibandingkan dengan SPG yang tidak menggunakan hak sepatu tinggi.

\section{Uji persyaratan analisis}

Berdasarkan hasil perhitungan menggunakan uji Kolmogorov-Smirnov dari waktu yang diperoleh SPG menggunakan hak sepatu tinggi nilai probabilitas (p-value) sebesar 0.163 dan SPG yang tidak menggunakan hak sepatu tinggi nilai probabilitas (p-value) sebesar 0.155. Suatu data dinyatakan berdistribusi normal jika probabilitasnya lebih besar dari 0.05 . Hasil uji menunjukkan nilai probabilitas kedua data sebesar 0.163 dan 0.155 maka dapat disimpulkan bahwa data berasal dari populasi yang berdistribusi normal. Hasil uji ini selanjutnya digunakan untuk penggujian hipotesis menggunakan uji t.

\section{BAHASAN}

\section{Karakteristik Subjek Penelitian}

Penelitian ini merupakan penelitian observasional dengan menggunakan desain penelitian cross sectional, untuk mengetahui pengaruh penggunaan sepatu hak tinggi

Tabel 1. Waktu treadmill subjek penelitian

\begin{tabular}{cccccc}
\hline Subjek Penelitian & $\begin{array}{c}\text { Jumlah } \\
\text { Subjek } \\
\text { (orang) }\end{array}$ & $\begin{array}{c}\text { Rata - rata } \\
\text { (detik) }\end{array}$ & $\begin{array}{c}\text { Simpangan } \\
\text { Baku (detik) }\end{array}$ & $\begin{array}{c}\text { Nilai } \\
\text { Maksimum } \\
\text { (detik) }\end{array}$ & $\begin{array}{c}\text { Nilai } \\
\text { Minimum } \\
\text { (detik) }\end{array}$ \\
\hline Hak Tinggi & 30 & 170,57 & 48,954 & 255 & 110 \\
Bukan Hak Tinggi & 30 & 284,07 & 66,460 & 401 & 200 \\
\hline
\end{tabular}


terhadap risiko timbulnya varises pada tungkai bawah pada SPG (Sales Promotion Girls) Matahari Departement Store Manado. Populasi penelitian ini adalah SPG yang bekerja di Matahari Departement Store Manado. Sampel penelitian 60 orang SPG yang telah memenuhi persyaratan inklusi dan ekslusi, dimana penelitian dilakukan pada bulan November 2012 sampai Januari 2013. SPG yang menggunakan hak sepatu tujuh sentimeter sebanyak 11 orang dengan presentase $18.33 \%$, SPG yang menggunakan hak lima sentimeter sebanyak 19 orang dengan presentase $31.67 \%$ sedangkan SPG yang menggunakan hak sepatu kurang dari lima sentimeter sebanyak 30 orang dengan presentase $50 \%$. Sebagian besar dari subjek penelitian menggunakan sepatu berhak lima sentimeter, akan tetapi penggunaan hak dengan tinggi tujuh sentimeter cukup banyak.

Berdasarkan perolehan data dan perhitungan saat dilakukan treadmill, SPG yang menggunakan hak sepatu 5-7 cm termasuk dalam kategori menggunakan sepatu hak tinggi terdiri dari 30 orang memiliki rata-rata waktu 170,57 detik, standar deviasi 48,954, nilai maksimum 255 detik sedangkan nilai minimum 110 detik. Untuk SPG yang menggunakan hak sepatu kurang dari lima sentimeter termasuk tidak menggunakan sepatu hak tinggi terdiri dari 30 orang memiliki rata-rata 284,07 detik, standar deviasi 66,460, nilai maksimum 401 detik dan nilai minimum 200 detik. Dapat disimpulkan bahwa rata-rata waktu untuk SPG yang memakai hak sepatu tinggi lebih kecil atau lebih cepat dibandingkan dengan SPG yang tidak menggunakan hak sepatu tinggi.

\section{Varises}

Varises atau vena varikosa adalah pembuluh darah balik yang abnormal dan tampak berkelok-kelok yang terlihat hanya pada permukaan kulit. Hal ini secara umum terjadi pada tungkai bawah, tetapi dapat juga mengenai bagian lain pada tubuh.,

Varises adalah keadaan dimana fungsi katup-katup vena bekerja tidak semestinya akibat peregangan berlebihan oleh karena meningkatnya tekanan vena dalam jangka waktu lama yang ditandai dengan penonjolan vena yang besar dan tampak di bawah kulit seluruh tungkai terutama tungkai bawah. Pada orang-orang tertentu pembuluh balik yang terdapat di tungkai dapat dengan mudahnya mekar atau bengkak. Varises biasanya dapat terjadi dimana-mana, tetapi biasanya yang paling sering nampak pada tungkai bawah dan kaki, dimana varises menyerang orang yang biasa berdiri terlalu lama dan apalagi dengan menggunakan sepatu hak tinggi. ${ }^{9}$

Secara biomekanis, penggunaan alas kaki dengan hak tinggi mengakibatkan kaki melorot ke depan dan mengakibatkan tekanan yang besar di bagian metatarsal kaki (bagian kaki sekitar jari). ${ }^{10,11}$ Akibatnya tungkai kaki naik, postur tubuh bagian atas berubah demi menjaga kesetimbangan dengan membuat tulang belakang semakin tegak. Akibat dari adanya paksaan ini, postur tulang belakang terutama bagian pinggang menjadi semakin cekung (lordosis). ${ }^{12}$

Casey Kerrigan, seorang profesor medis dan rehabilitasi di Universitas Virginia, USA, juga telah melakukan studi tentang bahaya sepatu hak tinggi bagi kesehatan sejak tahun 1990-an. Hasilnya, selain dapat menyebabkan sakit punggung dan nyeri pada kaki, penggunaan sepatu hak tinggi juga menyebabkan wanita menderita nyeri lutut dua kali lebih banyak dari lakilaki. Riset yang dilakukan Dr. Kerrigan menunjukkan memakai stilleto menyebabkan tekanan pada lutut dan pinggul meningkat 25\% setiap kali melangkah. ${ }^{12,13}$

U.S. Departement of Health and Human Service, faktor lain yang dapat menimbulkan varises yaitu keturunan atau genetik, umur, jenis kelamin, kehamilan, obesitas dan posisi berdiri atau duduk dalam waktu yang lama. ${ }^{4,14}$

Varises tidak mengakibatkan masalah yang serius. Namun dalam beberapa kasus, varises dapat menyebabkan masalah kesehatan, antara lain luka atau borok pada kulit, perdarahan, tromboflebitis, trombosis vena dalam. ${ }^{4,7,14}$

Penderita varises biasanya merasakan nyeri dan keram pada kaki, terutama pada 
saat berdiri maupun saat beraktivitas dan nyeri berkurang jika istirahat. Nyeri ini bisa disebut sebagai claudication intermitten. Waktu dimana gejala-gejala ini timbul dinamakan claudication time. Claudication time dapat diukur dengan menggunakan pengukuran Vascular System yaitu subjek penelitian diminta berlari pada treadmill dengan kecepatan 8,8 mph selama lima menit. Hasil positif didapati jika setelah lima menit dilakukan kegiatan tersebut subjek peneliti merasakan nyeri pada betis. ${ }^{15}$

Penelitian sebelumnya oleh Yurnila Ningsih Ahcmad yang dilakukan pada 60 orang SPG Matahari Solo Square di Surakarta, dimana 35 orang SPG yang memenuhi kriteria inklusi dan 25 orang SPG yang menggunakan sepatu hak tinggi kurang dari lima sentimeter. Hasil perhitungan statistik diperoleh nilai t hitung sebesar 10.850 dan nilai probabilitas 0.000. Ho ditolak dan disimpulkan bahwa Hipotesis alternatif yang menyatakan ada pengaruh penggunaan sepatu hak tinggi terhadap risiko timbulnya varises pada tungkai bawah terbukti kebenarannya secara statistik.

Hasil analisa pada penelitian ini secara statistik yaitu berdasarkan hasil perhitungan diperoleh nilai t hitung sebesar 7,531 dan nilai probabilitas 0,0001 . Ho ditolak jika probabilitas kurang dari 0,05 karena nilai probabilitas yang didapat dalam perhitungan kurang dari 0,05 maka dengan demikian Ho ditolak dan disimpulkan bahwa Hipotesis alternatif yang menyatakan ada pengaruh penggunaan sepatu hak tinggi terhadap risiko timbulnya varises pada tungkai bawah. Berdasarkan keterangan di atas, dapat disimpulkan bahwa terdapat pengaruh penggunaan sepatu hak tinggi terhadap risiko timbulnya varises pada tungkai bawah.

\section{SIMPULAN}

Secara statistik ditetapkan bahwa terdapat pengaruh yang bermakna tentang penggunaan sepatu hak tinggi dengan risiko timbulnya varises pada tungkai bawah. Berdasarkan hasil penelitian, dikemukakan saran untuk penelitian-penelitian selanjutnya agar dapat memperbanyak sampel yang diteliti.

\section{DAFTAR PUSTAKA}

1. Siahaan, A. C. Hak Sepatu Tinggi, Berbahayakah. [Cited 2012 Oct 20]. Available from

http://www.infoanda.com/linksfollow.php?li =www.kompas.co.id $/ /$ kesehatan $/$ news $/ 0605 /$ 21/125852.htm.

2. Christensen K, High-Heeled Shoes and Musculoskeletal Problems. Dynamic Chiropractic. 2000:1-4.

3. Curran S, Holliday J, Watkeys L, Influence of High Heeled Footwear and Pre-fabricated Foot Orthoses on Energy Efficiency in Ambulation. The Foot and Ankle Online Journal. 2010.

4. U.S. Department of Health and Human Services, Office on Women's Health; Varicose Veins and Spider Veins. $2010: 1-7$

5. Vascular Web; Vericose Veins. [Cited 2013 Feb 14]. Available from: http://www.vascularweb.org/vascularhealth/ Pages/varicose-veins.aspx.

6. Mayo Clinic; Claudication. [Cited 2012 Oct 21]. Available from: http://www.mayoclinic.com/health/claudicat ion/DS01052.

7. Mansjoer, A., Suprohaita, Wardhani, W. I., Setiowulan, W. Bedah Vaskular; Varises. Kapita Selekta Kedokteran Jilid 2. Edisi 3. Jakarta: Media Aesculapius Fakultas Kedokteran Universitas Indonesia, 2009; p.361.

8. Price S, Wilson L. Penyakit Pembuluh Darah; Varises. Dalam : Hartanto H, Wulansari P, Susi N, Mahanani DA, editor. Patofisiologi Volume 1. Edisi 6. Jakarta: EG, 2006; p.681.

9. Guyton AC, Hall JE. Distensibilitas Vaskular, Serta Fungsi Sistem Vena dan Arteri; Kegagalan Katup Vena yang Menyebabkan "Varises". Dalam : Rachman LY, Hartanto H, Novrianti A, Wulandari N, editor. Buku Ajar Fisiologi Kedokteran. Edisi ke-11. Jakarta : EGC, 2008; p185-186.

10. Mayo Clinic; Metatarsalgia. [Cited 2012 Oct 21]. Available from: http://www.mayoclinic.com/health/metatars algia/DS00496.

11. River Side Online; Foot problems in women: High heels and your health. [Cited 2012 Oct 21]. Available from: 
http://www.riversideonline.com/health_refer ence/Articles/WO00114.cfm.

12. Kerrigan DC, Lelas JL, Karvosky ME: Women's shoes and knee osteoarthritis. The Lancet; 2001 : 1097-1098.

13. Kerrigan DC, Todd MK, Riley PO: Knee osteoarthritis and high heeled shoes. The Lancet; 1998 : 1399-1401.
14. Kumar V, Cotran RS, Robbins SL. Pembuluh Darah; Vena Varikosa. Dalam : Hartanto H, Darmaniah N, Wulandari N, editor. Buku Ajar Patologi Volume 2. Edisi 7. Jakarta : EGC; 2007 : 395-396.

15. Gray, JC. Diagnosa Of Intermittent Vascular Claudication In a Patient With a Diagnosa Of Sciatica. Physical Therapy. 1999 : 582590. 